\title{
Análise do perfil, da percepção ambiental e da qualidade da experiência dos visitantes da Serra do Cipó (MG)
}

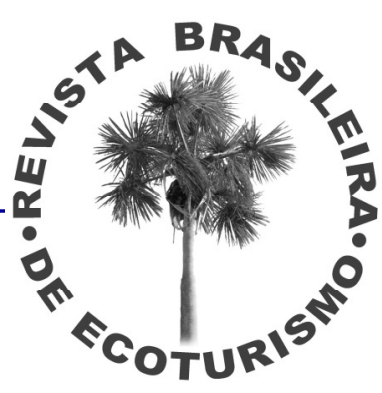

\author{
Renata Ferreira Campos, Ferdinando Filetto
}

\section{RESUMO}

O objetivo deste trabalho foi conhecer o perfil dos visitantes da região da Serra do Cipó e avaliar a qualidade da experiência da visita. A região da Serra do Cipó dista pouco mais de $100 \mathrm{~km}$ de Belo Horizonte e possui duas Unidades de Conservação: O Parque Nacional da Serra do Cipó e, em seu entorno, a Área de Proteção Ambiental (APA) Morro da Pedreira. Com o propósito de buscar informações que contribuam com o planejamento turístico do local, foram analisados 134 questionários, aplicados entre os meses de março e maio de 2009. Verificou-se que a maioria dos visitantes pode ser considerada como "ecoturista", pois o perfil encaixa-se dentro do comumente proposto na literatura. Predominam os visitantes jovens, com alto nível de escolaridade, provenientes de Belo Horizonte e região metropolitana, que viajam acompanhados por amigos, permanecendo no local apenas durante o final de semana. A maioria dos entrevistados tomou conhecimento da existência do destino por meio de divulgação pessoal, e foi motivada pelo contato com cachoeira e/ou rio e pelas trilhas em si. Os visitantes possuem, ainda, um bom nível de consciência ambiental. A maioria está de acordo com as taxas de visitação cobradas e com o estabelecimento de limites de entrada nos atrativos, além de estarem dispostos a seguir regras de conservação em favor da natureza. De uma maneira geral, os visitantes da Serra do Cipó mostraram-se satisfeitos com os serviços oferecidos na região e com a visita, como um todo. A quase totalidade dos entrevistados apresentou a intenção de retorno ao local. Dessa forma, a utilização dos questionários se mostrou eficiente para caracterizar o perfil dos visitantes e forneceu subsídios para endossar os objetivos de conservação ambiental e direcionamento das atividades de planejamento turístico e de monitoramento da satisfação do visitante, bem como de educação e interpretação ambiental.

PALAVRAS-CHAVE: Serra do Cipó; Perfil de Visitantes; Ecoturismo. 


\section{Analysis of the visitors of Serra do Cipó/MG/Brazil's profile, quality of experi- ence and environmental feeling}

\section{ABSTRACT}

The aim of this work is to know the visitors of Serra do Cipó region and to evaluate the quality of this experience. Serra do Cipo is just over $100 \mathrm{~km}$ from Belo Horizonte and covers two protected areas: Serra do Cipó National Park and its surroundings, Morro da Pedreira Environmental Protection Area (APA). Aiming to seek information to contribute to the local tourism planning, we analyzed 134 questionnaires applied between March and May, 2009. It was found that the majority of visitors can be considered "ecotourist", as their profiles fit in the commonly proposed in the literature. Young visitors predominate, with high educational standards, coming from Belo Horizonte and its metropolitan areas, traveling with friends, staying at the place only for the weekend. Most enterviewed ones knew about the destiny through friends, due to an existent waterfall and / or the river and trails. Visitors have also a good level of environmental consciousness. Most of them agree with the rates charged, the limits to access the features and to follow the rules in favor of nature conservation. In general, visitors to Serra do Cipó were happy with services rendered in the region and the visit itself. Almost all the interviewed people stated the intention of a later return. Thus, those questionnaires were efficient to characterize the profile of visitors and provide information to endorse environmental conservation goals, to direct the activities of tourism planning, to monitor visitor's satisfaction, environmental interpretation and education as well.

KEYWORDS: Serra do Cipó; Visitors Profile; Ecotourism.

\section{Introdução}

O turismo nos dias de hoje vem se mostrando como um grande consumidor da natureza. Para Ruschmann (1997) sua evolução, nas últimas décadas, ocorreu como consequência da "busca do verde" e da "fuga" dos tumultos dos grandes conglomerados urbanos pelas pessoas que tentam recuperar seu equilíbrio físico, e também psicológico, estabelecendo um maior contanto com os ambientes naturais durante seu tempo de lazer.

Essa busca por atrativos naturais tem levado um relevante número de turistas a parques e locais que possam oferecer este contato entre homem e natureza. Assim se inserem as Unidades de Conservação (UC) como áreas que se enquadram neste contexto, capazes de proporcionar aos seus visitantes, a satisfação de uma relação parcimoniosa, além de poder atuar não somente na preservação dos recursos naturais, mas também, como locais de aprendizagem e sensibilização da comunidade acerca da problemática ambiental (SILVA; COSTA NETO, 2007). 
Niefer (2002) acredita que a visita a áreas naturais protegidas pode ser a grande chance de influenciar no processo de aprendizado dos turistas que procuram as Unidades de Conservação. Porém, a autora diz que, infelizmente, a sociedade em geral não conhece e não compreende a importância das Unidades de Conservação. Realmente parece difícil valorizar o que não se conhece. No entanto, atividades simples de Educação Ambiental, com informações e esclarecimentos sobre as UC's, podem reverter essa situação e ainda evitar os impactos ambientais sobre tais áreas.

Os visitantes de UC's podem ser, ainda, valiosos aliados para a administração destas áreas, tanto para apoiar a mesma nos seus esforços para a conservação como, indiretamente, pelo aumento da renda das populações locais. Neste sentido, Niefer (2002) lembra que é indispensável que os administradores de UC's tenham conhecimento das características dos seus visitantes, tanto para elaborar estratégias de manejo dos visitantes como para tornar satisfatória a experiência turística.

Dessa forma, conhecer as características básicas dos visitantes, como: idade, sexo, escolaridade, tempo de permanência no local, percepção ambiental e ecológica, etc., permite compreender melhor quem, quantos, quando, onde e de que modo as pessoas recebem os benefícios das áreas silvestres, sejam eles psicológicos, comportamentais ou sociais. Tais informações podem ajudar os administradores e gestores públicos e também os pesquisadores, a compreender o comportamento dos usuários, bem como as causas e possíveis soluções dos impactos ecológicos causados pelos visitantes.

A caracterização dos turistas que visitam a Serra do Cipó, assim como a relação que estabelecem com o local, é uma forma importante de orientação para as ações de planejamento e manejo do turismo na região, uma vez que as atividades turísticas em Unidades de Conservação são consideradas, por muitos, uma ameaça para a preservação do meio ambiente. No entanto, se forem bem planejadas e conduzidas, tais atividades podem ser sinônimo de preservação, conservação e revitalização de ambientes naturais e culturais.

Assim, o presente trabalho tem como objetivo geral a caracterização do perfil visitantes da Serra do Cipó, de forma a propiciar um melhor planejamento do uso público da região e, consequentemente, garantir uma experiência rica e agradável aos visitantes sem causar impactos significativos aos recursos socioeconômicos, culturais e naturais da área.

São objetivos específicos:

- Conhecer o perfil dos visitantes da região da Serra do Cipó;

- Analisar a consciência e as atitudes ambientais dos visitantes da Serra do Cipó;

- Avaliar a qualidade da experiência da visita à Serra do Cipó. 


\section{Caracterização da área e metodologia da pesquisa}

A área de estudo da pesquisa é comumente chamada de Serra do Cipó, e está situada na parte central do Estado de Minas Gerais entre as coordenadas 19 12' e

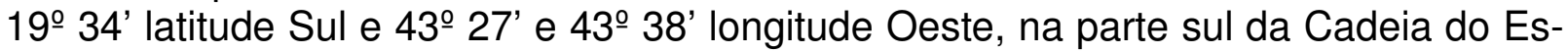
pinhaço. O distrito da Serra do Cipó, anteriormente denominado Cardeal Mota (alteração providenciada em 2003 através de lei municipal), pertence ao município de Santana do Riacho e localiza-se a cerca de $100 \mathrm{~km}$ a norte de Belo Horizonte. O acesso se dá pela rodovia MG-010.

O movimento para a transformação dessa região em uma Unidade de Conservação foi encabeçado pelos próprios moradores, e em 1975, finalmente, eles viram concretizados seus anseios através da criação do Parque Estadual da Serra do Cipó, que, a princípio, possuía área de 27.600 hectares. Em 25 de setembro de 1984, quando já havia adquirido mais 14.400 hectares, foi publicada, no Diário Oficial da União, a criação do Parque Nacional da Serra do Cipó. Desde então, esteve sob jurisdição do Instituto Brasileiro de Meio Ambiente e dos Recursos Renováveis - IBAMA, até a criação do Instituto Chico Mendes de Conservação da Biodiversidade - ICMBio, que passou a responder pelas Unidades de Conservação federais a partir de maio de 2007 (IBAMA, 1994).

O Parque apresenta 31.733 hectares e $120 \mathrm{~km}$ de perímetro, estendendo-se pelos municípios de Jaboticatubas, Santana do Riacho, Morro do Pilar e Itambé do Mato Dentro. Atualmente é permitida a entrada de, no máximo, 300 pessoas por dia e é cobrada uma taxa de $R \$ 3,00$ (três reais). O PARNA Serra do Cipó, consagrado como um dos mais belos e importantes destinos ecoturísticos do país, é sempre visitado por cientistas e, principalmente, turistas em busca de suas belezas naturais, suas inúmeras cachoeiras, rios, cânions, vegetações exuberantes, paredões para prática de escalada, canyoning, rapel, cavalgadas, cavernas, trekking e trilhas para prática de "moutain bike".

A proteção do Parque Nacional da Serra do Cipó e de seu entorno foi incrementada, com estabelecimento da Área de Proteção Ambiental (APA) Morro da Pedreira, nome que homenageia uma enorme formação calcária localizada rente à fronteira do Parque e que sofreu com a exploração de mármore durante muitos anos. A APA morro da Pedreira possui uma área total de 110.431 hectares e compreende os municípios de Santana do Riacho, Conceição do Mato Dentro, Itambé do Mato Dentro, Morro do Pilar, Jaboticatubas, Taquaraçu de Minas, Itabira e Nova União.

As localizações do Parque Nacional da Serra do Cipó e da APA Morro da Pedreira são mostradas na Figura 1. 

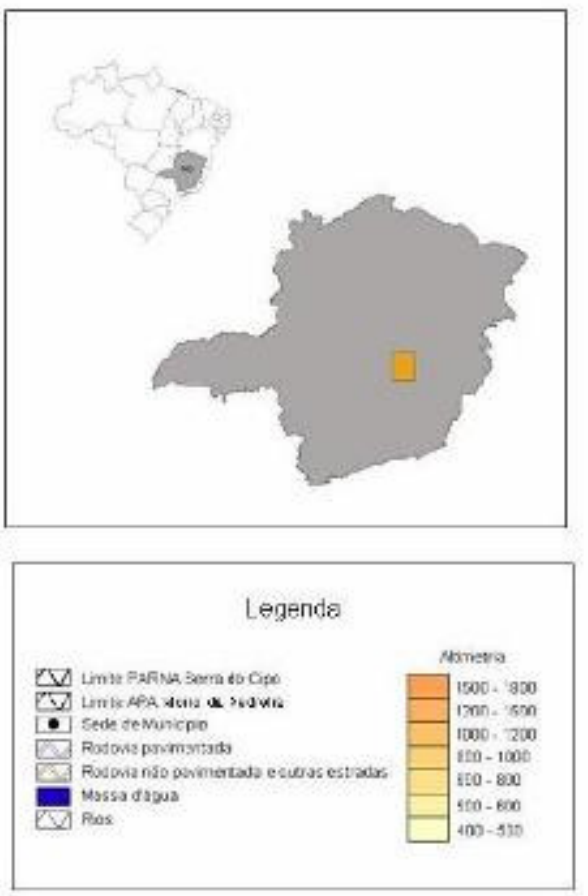

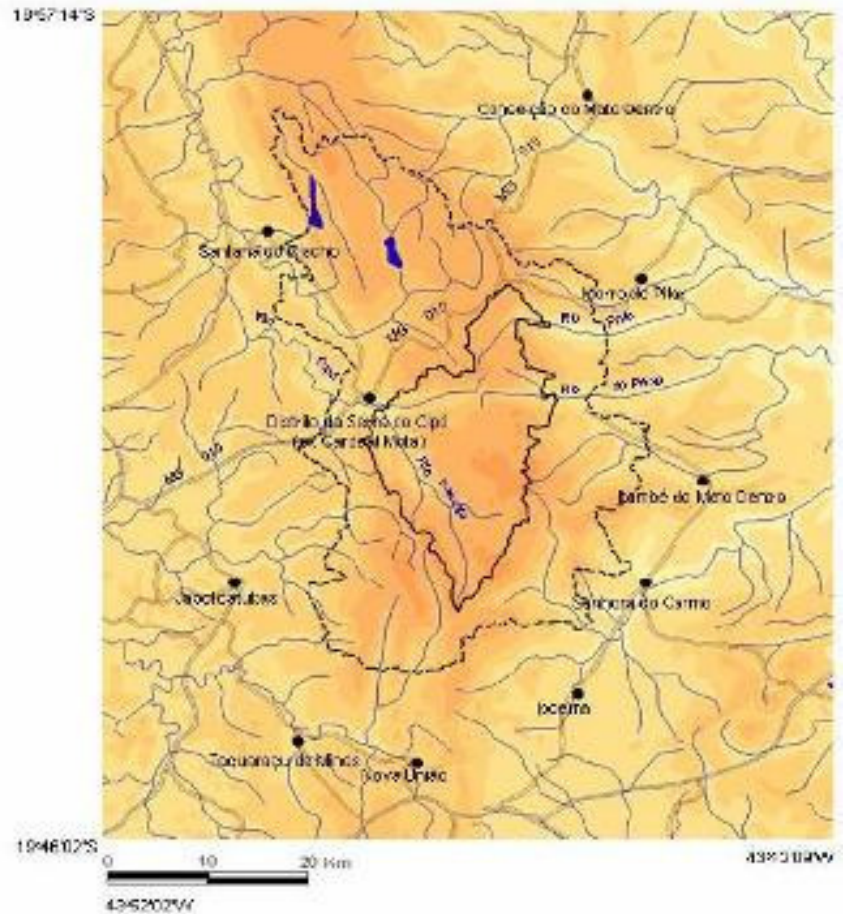

Figura 1: Localização do Parque Nacional da Serra do Cipó e da APA Morro da Pedreira. Fonte: SATO (2007).

Foi elaborado um questionário contendo 31 perguntas adaptadas dos estudos de Niefer, (2002); Muniz (2006); Dutra et al. (2008); Ribeiro e Cronenberger (2007), Katoka (2004), e Alencar (2007), buscando informações quantitativas e qualitativas sobre o perfil, a percepção ambiental e a qualidade da experiência dos visitantes da Serra do Cipó.

O tipo de amostra utilizada foi a "não probabilística por conveniência" (ou acidental), onde o elemento pesquisado é selecionado por estar disponível no local e no momento em que a pesquisa estava sendo realizada (MATTAR, 1997). Os dados foram coletados através de aplicação de questionários respondidos pelo próprio entrevistado, que na média levaram de 7 a 15 minutos, cada.

Um pré-teste com 24 entrevistas obtidas nos dias 28 e 29 de março de 2009 foi realizado e resultou em algumas poucas modificações no questionário original. Como foram apenas retiradas algumas questões, estes questionários puderam ser aproveitados para análise final. Foram aplicados um total 134 questionários, no período de 3 de abril a de 24 de maio de 2009. 


\section{Resultados e Discussão}

\section{O perfil do visitante}

A grande maioria dos visitantes (85\%) é originária de Belo Horizonte e região metropolitana. O fácil acesso à região e a curta distância, cerca de $100 \mathrm{~km}$, entre Belo Horizonte e Santana do Riacho favorece a busca por esse destino, principalmente aos finais de semana. Os outros $15 \%$ dos visitantes são do interior do Estado de Minas Gerais, $10 \%$, e de outros estados, apenas $5 \%$. Resultado semelhante foi encontrado por Sato (2007) que observou, para o mesmo local, a predominância de visitantes de Belo Horizonte $(65 \%)$ e de outras cidades mineiras $(22 \%)$, totalizando $87 \%$ para o estado de Minas Gerais.

Com relação ao gênero podemos dizer que não há diferença significativa, visto que foram entrevistadas 69 mulheres e 65 homens, ou seja, $51 \%$ de mulheres e $49 \%$ de homens. É válido lembrar que todas as pessoas entrevistadas estavam viajando com pelo menos mais uma pessoa, e o questionário era respondido por apenas uma pessoa de cada grupo, sendo talvez, as mulheres mais solícitas a responder o questionário. Moutinho (2000 apud NIEFER, 2002) relata que o número de mulheres que viajam sozinhas ou em grupos, aumentou consideravelmente nos últimos anos, sendo isto um fenômeno global devido à sua emancipação social e econômica.

A Figura 2 nos mostra que quase metade dos visitantes tem entre 25 e 34 anos. Porém é bastante significativa também, a faixa etária de 19 a 24 anos, o que caracteriza um perfil de turistas jovens e adultos, que se enquadra no perfil de ecoturistas estudados por Ruschmann (2002). Em outros parques brasileiros, Ribeiro e Cronenberger (2007) encontraram um predomínio de visitantes na idade entre 25 a 45 anos, correspondendo a $56 \%$ dos respondentes. E Melo et al. (2008), observaram uma maior porcentagem (43\%) de pessoas na faixa de 26 a 40 anos e de 19 a 25 anos (42\%). Sendo que pessoas acima de 40 anos somaram apenas $8 \%$ e abaixo de 18 anos, $7 \%$ do total.

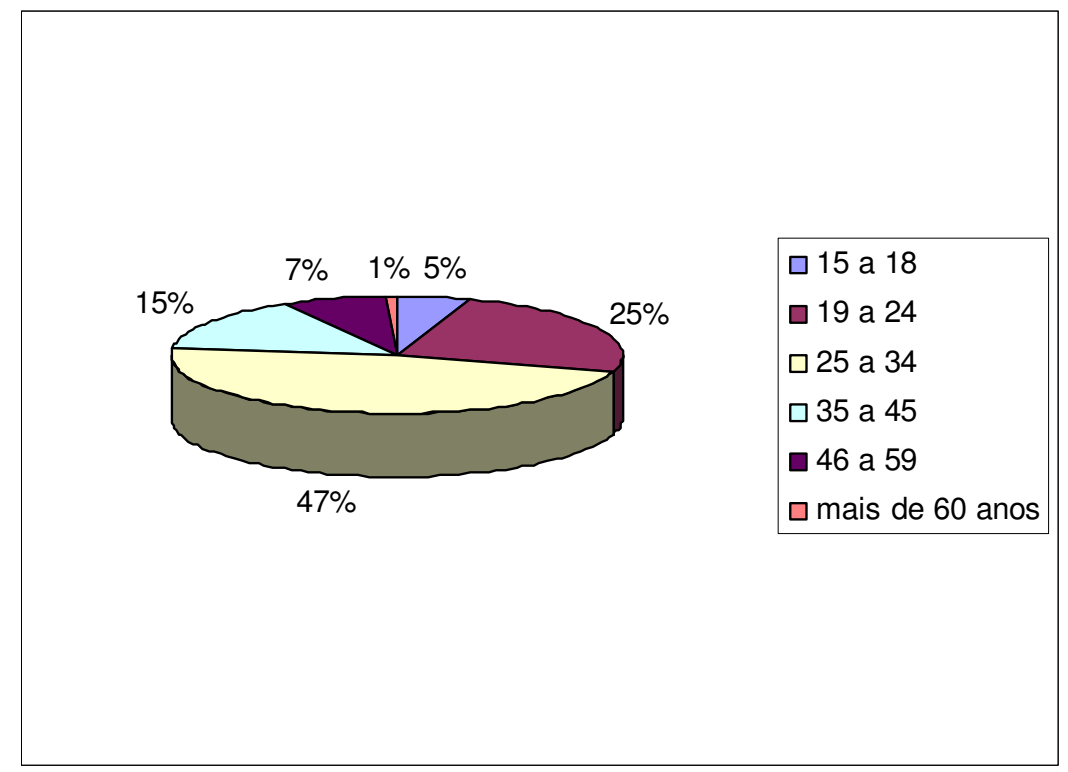

Figura 2: Idade dos visitantes. 
O nível de escolaridade observado foi considerado elevado, uma vez que a grande maioria (78\%) já completou o ensino superior ou está cursando-o. Sendo que destes, $27 \%$ possuem ou estão fazendo algum curso de pós-graduação, seja especialização, mestrado ou doutorado (Figura 3). De acordo com os estudos de Barros e Dines (2000), os ecoturistas apresentam um bom nível de escolaridade e são, normalmente, mais receptivos e conscientes das necessidades de conservação ambiental e das atratividades ecoturísticas e, se orientados, podem apresentar alto grau de comprometimento para a conservação destes locais. Espera-se que isto favoreça a implantação de projetos de Educação Ambiental.

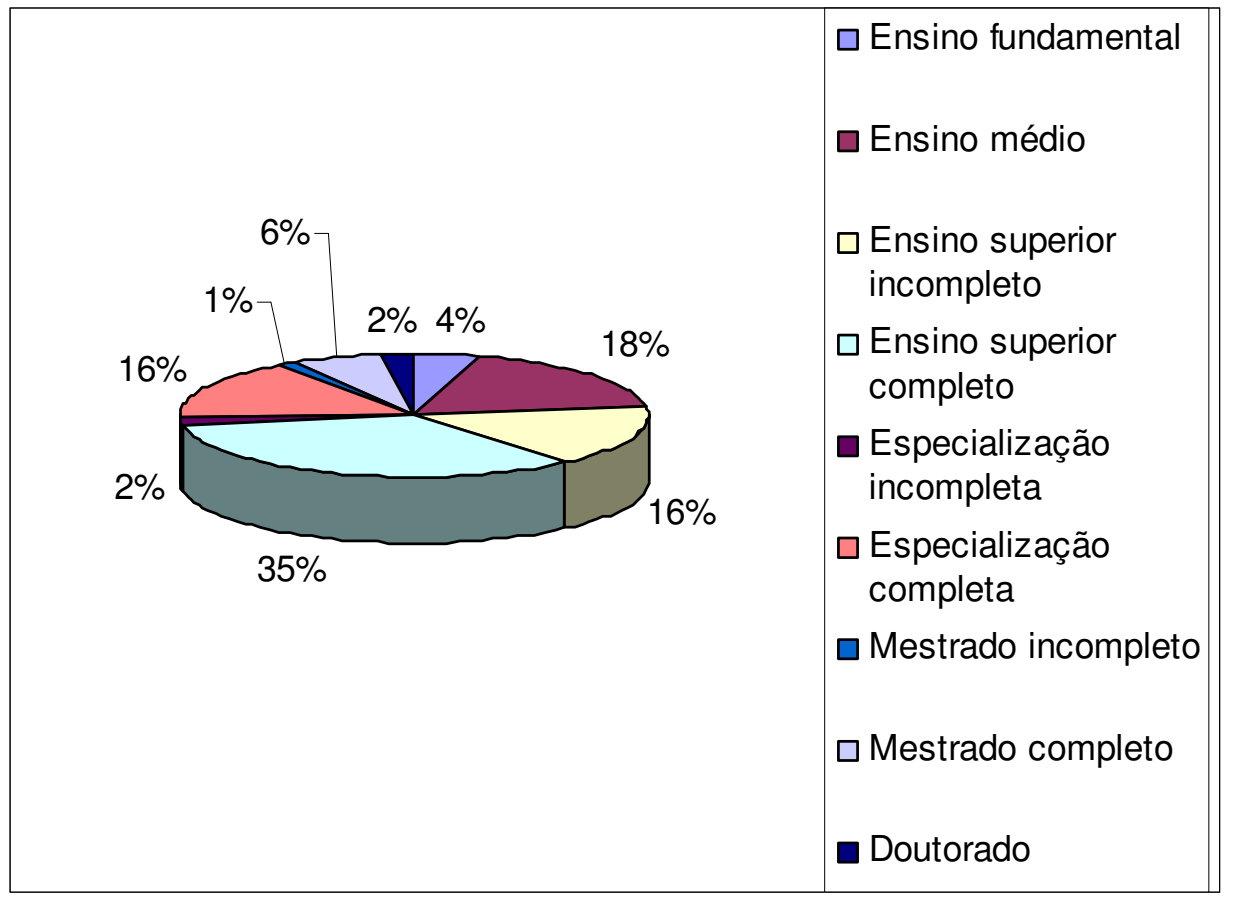

Figura 3: Nível de escolaridade.

Em relação à renda individual o resultado foi bastante equilibrado. A maioria dos entrevistados, $47 \%$, disse ganhar até $\mathrm{R} \$ 2000,00$ mensais, $6 \%$ declararam não ter renda pessoal, o que condiz com o perfil de jovens estudantes. Porém $22 \%$ ganham entre $R \$ 2000,00$ e $R \$ 4000,00$. E os outros $25 \%$ têm uma renda individual superior a $\mathrm{R} \$ 4000,00$. Também nas ilhas do Mel e Superagui, $29,34 \%$ e $21,71 \%$ dos entrevistados recebem mais de $R \$ 4000.00$ mensais, respectivamente, demonstrando um maior poder aquisitivo dos visitantes de áreas naturais em relação à maioria da população (NIEFER, 2002). Fato comprovado por Ruschmann (2002) que cita que os ecoturistas brasileiros possuem renda média superior a $R \$ 3000,00$ mensais (Figura 4). 


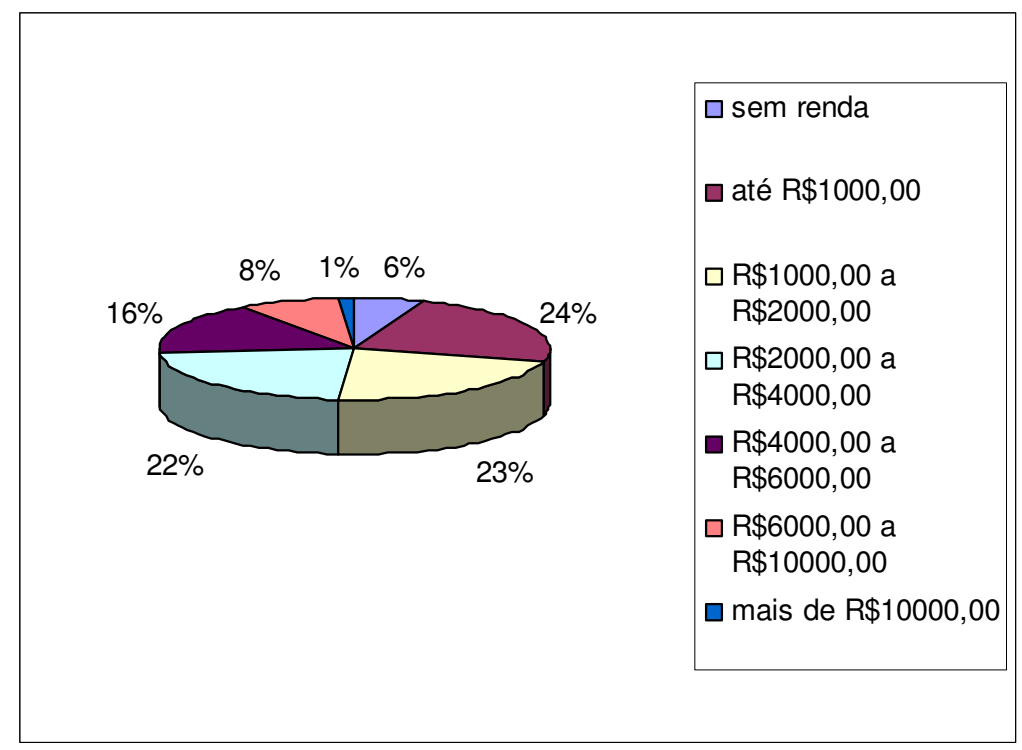

Figura 4: Renda mensal individual.

Apesar de a situação socioeconômica não determinar a eficácia do processo de acordo com os princípios de Educação Ambiental, esse fato pode contribuir, e muito, para que um programa de educação do visitante seja bem recebido e aceito pelo público, pois as pessoas que visitam os parques já possuem uma bagagem educacional que as ajuda a compreender a importância das atitudes e ações de todos nas áreas naturais (LADEIRA et al., 2007).

\section{Características da viagem}

A grande maioria dos entrevistados viaja com amigos e família, $48 \%$ e $31 \%$ respectivamente. Outros $19 \%$ disseram viajar com namorado ou namorada e apenas $2 \%$ viaja sozinho. O alto número de visitantes que viajam com amigos, provavelmente, é explicado devido à grande presença do público jovem encontrado. A maioria dos casais também é formada por pessoas jovens.

Dutra et al. (2008) obtiveram resultados semelhantes no PE do Jalapão, onde $43 \%$ dos entrevistados estavam viajando com amigos e $26 \%$ com a família. Já no PN de Superagui, Niefer (2002) observou que 37\% dos visitantes viajam com os amigos e $35 \%$ com a família.

Informações sobre o tamanho dos grupos de visitantes são importantes para avaliar o impacto recreativo em áreas naturais e também para auxiliar o planejamento, a implementação e a avaliação das estratégias de manejo voltadas para grupos (BARROS, 2003). Na Serra do Cipó, $41 \%$ das pessoas viajam em grupos formados por duas pessoas e $37 \%$ formados por três a cinco pessoas. O que, somados aos $2 \%$ dos entrevistados que viajam sozinhos, como dito anteriormente, dá um total de $80 \%$. 
Ou seja, a grande maioria das pessoas que visitam a Serra do Cipó, o fazem em grupos de no máximo cinco pessoas.

Em suas pesquisas na também na Serra do Cipó, Gualtieri-Pinto et al. (2007) observaram que grupos maiores não demonstram interesse em conhecer as normas de utilização dos atrativos naturais do Parque. No entanto, grupos menores tendem a ser mais integrados às normas de conduta pessoal, percebendo melhor as nuances e diferenças que envolvem o comportamento humano em ambientes urbanizados e em ambientes naturais.

Em relação ao número de visitas que os entrevistados já fizeram à Serra do Cipó, a maioria (67\%) não o faz pela $1^{\circ}$ vez (Figura 5).

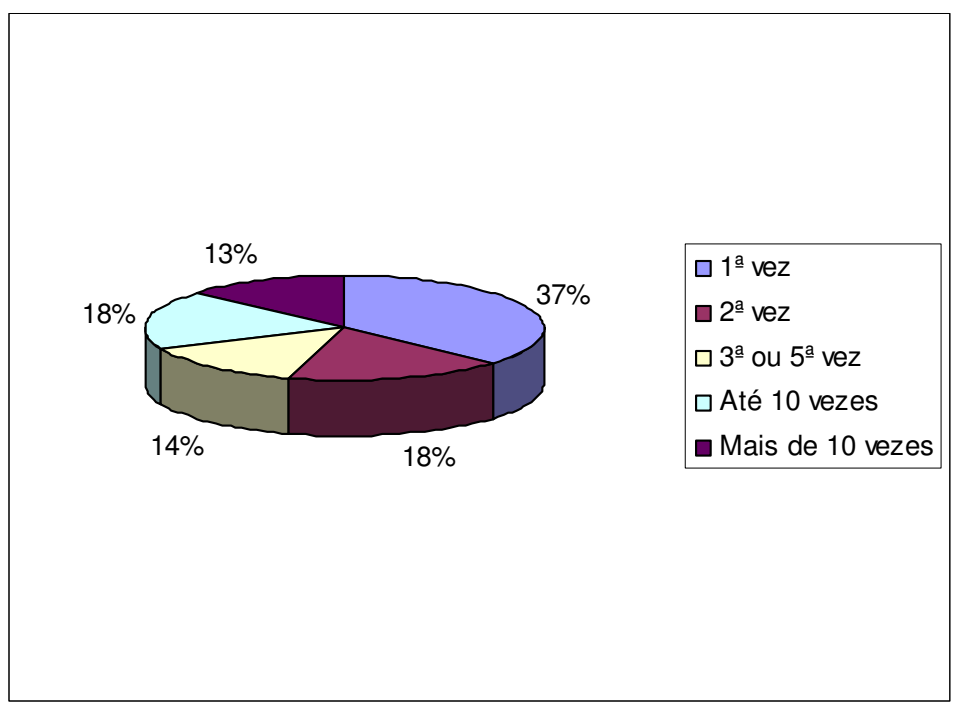

Figura 5: Número de visitas.

A frequência com que visitantes voltam ao mesmo destino, pode se transformar em um ótimo fator de conservação do ambiente. Quando as pessoas assumem um ambiente como seu, quando sentem que fazem parte daquele ambiente, dificilmente vão querer agredi-lo porque sabem que estarão agredindo a si mesmas. Ladeira et al. (2007) acreditam ainda que essa assiduidade do turista com o destino estabelece uma relação mais comprometida com os problemas socioambientais da região, e pode servir como instrumento de pressão junto ao poder público para solução de problemas identificados na localidade.

A maioria dos visitantes permaneceu na Serra do Cipó durante três dias (36\%) e dois dias (32\%). Fato que corrobora a sazonalidade do turismo no destino, onde as visitas ocorrem basicamente aos finais de semana. E ainda $24 \%$ dos entrevistados permaneceram apenas um dia na Serra. Esse fato se deve, provavelmente, à curta distância entre a região e Belo Horizonte. O que se torna um fator de alerta, pois mui- 
tos destes visitantes costumam organizar excursões e grupos grandes, o que pode causar impactos ambientais mais graves. Em geral, estes turistas aumentam pouco ou quase nada a renda da população, pois não costumam consumir muito nos bares/ restaurantes. Outro agravante é que os participantes destas excursões não criaram vínculos com o lugar visitado e em função disso têm menos preocupação em não criar impactos negativos (NIEFER, 2000).

Dos visitantes que permaneceram mais de um dia na Serra do Cipó, mais da metade se alojou em pousadas (55\%), seguido dos que alugaram casas $(20 \%)$, camping (13\%), casa de amigos (6\%), e apenas $2 \%$ ficaram hospedados em hotel - essa pequena porcentagem se justifica ao fato de existir apenas um hotel na região.

Também foi questionado aos visitantes, quais os motivos o levaram até a Serra do Cipó. Muitos dos entrevistados marcaram mais de uma motivação, sendo que todas as respostas foram consideradas. Portanto, a soma final ultrapassa $100 \%$. Os três motivos mais citados pelos respondentes foram: tomar banho de rio ou cachoeira; lazer e diversão e percorrer uma trilha (Figura 6).

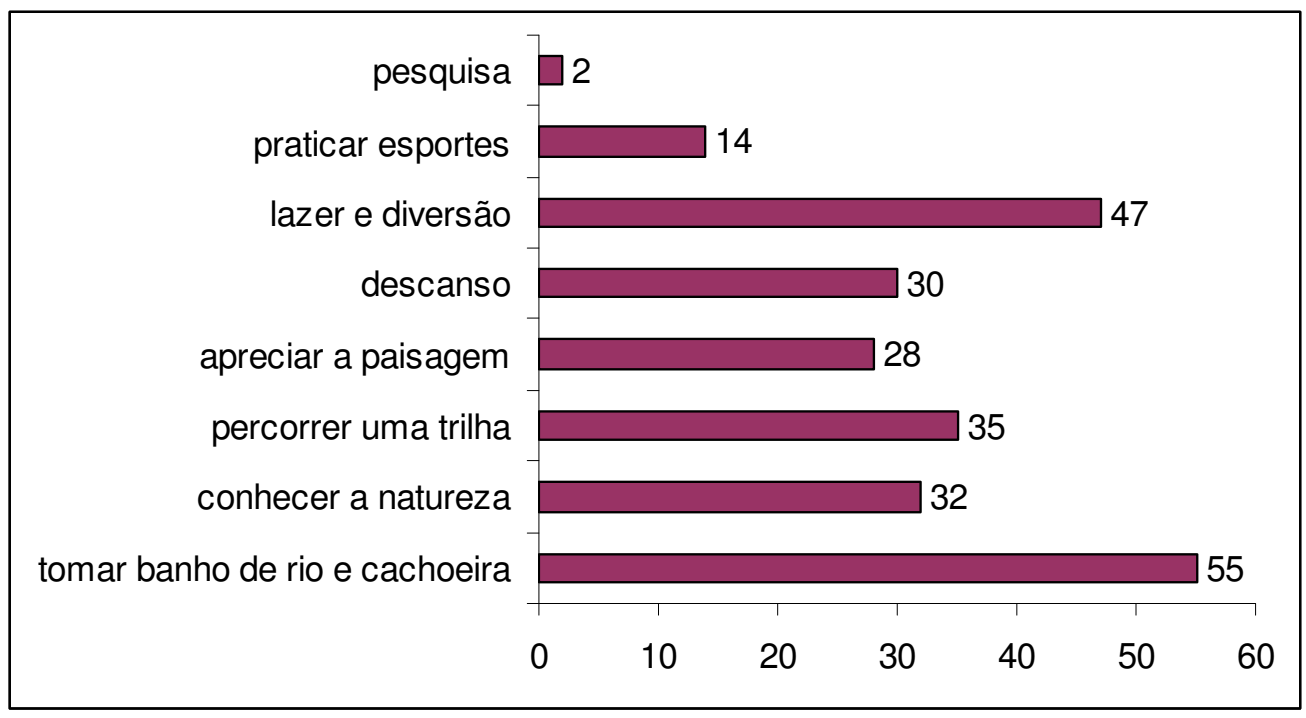

Figura 6: Motivação

Nota-se que há uma parcela de visitantes (47\%) que mencionaram o lazer como o principal motivo de sua visita. Provavelmente nesse caso, encontram-se os visitantes que frequentam a Serra do Cipó há mais tempo e já não a vêem talvez, como um destino turístico, mas como uma área de seu entorno habitual.

Os resultados da Figura 6 demonstram também que o maior interesse dos visitantes é chegar à cachoeira. Embora muitos também tenham citado razões como percorrer uma trilha e apreciar a paisagem. Seria interessante um trabalho de interpretação ambiental, chamando atenção do visitante para a valorização dos elementos na- 
turais ao longo da trilha, o que pode tornar esta atividade mais proveitosa e mais agradável do que, simplesmente, chegar ao destino final.

Para Ruschmann (1997), no Brasil, a "oportunidade de lazer e recreação" e o "descanso" têm prioridade, sendo que a paisagem intacta e o clima aparecem em terceiro lugar na ordem de importância dos estímulos que influenciam a decisão por uma destinação turística. O conhecimento das motivações que levam uma pessoa a visitar uma área natural é visto por Kataoka (2004) como fator importante para que seja avaliado se as expectativas destes visitantes estão de acordo com o que o parque pode oferecer.

A propaganda chamada de "boca em boca" foi o principal meio que os entrevistados tomaram conhecimento sobre a Serra do Cipó. 89\% dos visitantes ouviram falar sobre o destino através de amigos e parentes (Figura 7). Fato que é observado também em outros roteiros de Ecoturismo, como o Parque Estadual do lbitipoca (LADEIRA et al., 2007), o Parque Estadual da Ilha Anchieta (KATAOKA, 2004), o Parque Nacional da Serra dos Órgãos (RIBEIRO e CRONENBERGER, 2007) e as ilhas do Mel e do Superagui (NIEFER, 2002), bem como por Sato (2007) no próprio Parque Nacional da Serra do Cipó.

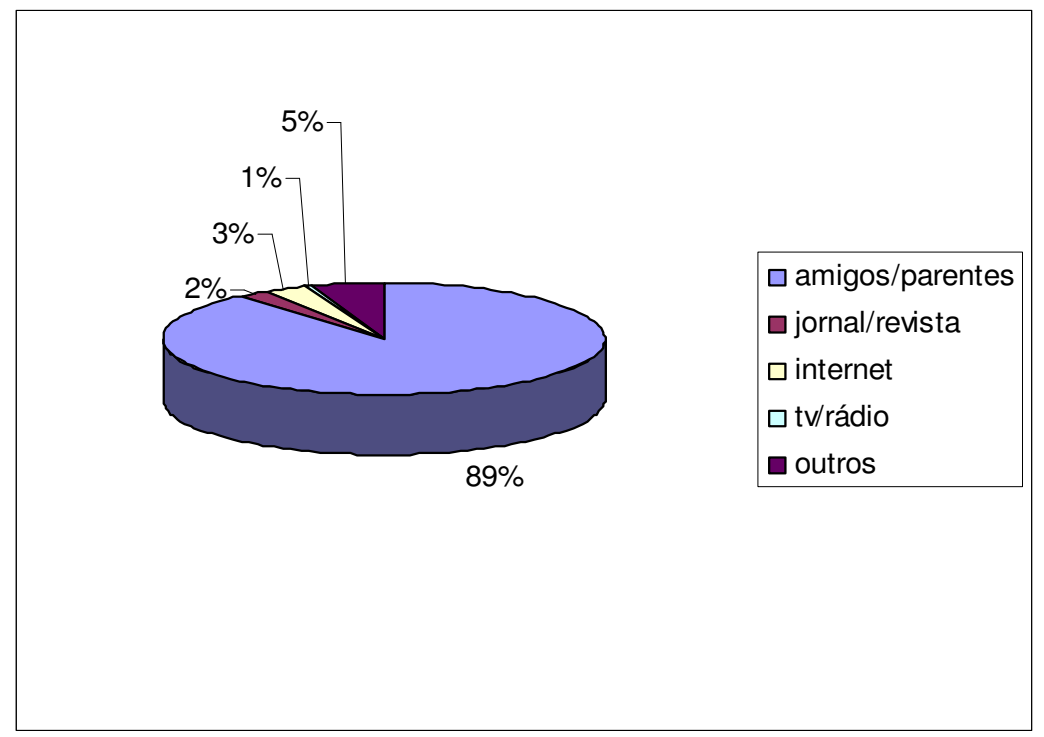

Figura 7: Forma de tomar conhecimento do destino.

Kataoka (2004) acredita que toda essa propaganda informal aumenta a importância de se entender as expectativas que os visitantes têm sobre a área visitada e de se monitorar os indicadores sociais de visitação. O conhecimento é importante também, para a administração do local, que pode utilizar esta informação, para divulgar programas específicos e aumentar ou diminuir o fluxo de visitantes. 


\section{Consciência e atitudes ambientais}

Quase a totalidade dos visitantes (97\%) sabia que estava visitando uma Unidade de Conservação. É um resultado bastante expressivo, que demonstra que os entrevistados têm o conhecimento de estarem em uma UC, embora não tenha sido verificado se sabiam identificar qual seria esta UC ou o que isso significa na prática. Provavelmente os resultados de uma pergunta nesse sentido não seriam tão expressivos. Kinker (2002) diz que a maioria das pessoas que procura um parque nacional tem pouca ou nenhuma noção do que seja o sistema de áreas protegidas, do que significa conservação da natureza e qual sua importância para o planeta, ou mesmo qual o papel do ser humano na natureza. Dessa forma, a visita a áreas naturais protegidas é considerada uma grande chance para influenciar esse processo de aprendizado.

A Serra do Cipó possui duas UC's: o Parque Nacional da Serra do Cipó, que é mais conhecido e divulgado pela mídia, porém possui uma área mais restrita e com um número menor de atrativos abertos à visitação do que a APA Morro da Pedreira, que se localiza no entorno do Parque, e apesar de ser bastante conhecida, e onde está localizada a maioria das atrações da Serra do Cipó, não é reconhecida pela maioria dos visitantes. Em entrevista a Sato (2007), o gerente do PARNA Serra do Cipó reconhece que

os visitantes, em sua grande maioria, não sabem qual é a diferença entre o PARNA e a APA, não sabem distingui-los, e não sabem onde fica cada um deles. Muitos sobem a Serra pensando que estão no parque, que é utilizado na mídia como atrativo, mas nem sabem que o parque tem uma portaria de acesso.

$\mathrm{Na}$ tentativa de reverter esse processo, Sato (2007) sugere que seja realizado um trabalho de divulgação e informação para que os visitantes tomem conhecimento sobre a distinção entre as UCs e a importância que cada uma possui. E apesar de os entrevistados reconhecerem que estão visitando uma Unidade de Conservação já ser um passo inicial importante, também deve estar associado ao conhecimento sobre a conduta adequada na área e seu valor como patrimônio natural, de forma a garantir que as atividades de uso público não causem impactos significativos, alertam Dutra et al. (2008).

Quando questionados a respeito da cobrança de taxas de visitação em Unidades de Conservação, a maioria dos entrevistados (83\%) disse concordar com a cobrança das taxas. Kinker (2002) considera que a questão da cobrança de ingressos tem gerado certa polêmica porque uma parte da população considera os parques bens públicos, uma herança nacional pela qual eles já pagam impostos, sendo uma obrigação dos governos responsabilizarem-se pela sua manutenção. Entretanto, há os que não se importam em pagar taxas, contanto que elas sejam revertidas em infraestruturas e serviços. Assim, aos visitantes que estavam de acordo com as taxas de visitação foi ainda perguntando se também estariam dispostos a pagar uma taxa de 
visitação mais alta para ter acesso a um local melhor estruturado, $54 \%$ do total de respondentes afirmaram que sim.

Vale lembrar que os preços cobrados para entrada nos atrativos na Serra do Cipó são bastante variáveis. No Parque Nacional, a taxa de visitação cobrada em 2009 era de $R \$ 3,00$. Já as atrações que estão localizadas fora dos limites do Parque, em áreas particulares, possuem preços mais altos, que variam entre $R \$ 10,00$ a $R \$ 20,00$. Diante disso, $64 \%$ dos visitantes que foram entrevistados no PARNA Serra do Cipó, disseram estar dispostos a pagar uma taxa de visitação maior que os $R \$ 3,00$ atuais. No entanto, apenas $19 \%$ dos entrevistados que responderam ao questionário em outras atrações, que não o Parque, disseram que pagariam uma taxa de visitação ainda maior.

Niefer (2002) sugere que já que uma boa parte dos entrevistados está disposta a pagar mais, poderia se pensar em arrecadar mais fundos, pedindo ajuda voluntária para projetos específicos que deveriam ser apresentados detalhadamente aos visitantes potenciais doadores. No entanto, pondera que estes resultados devem ser analisados com cuidado, visto que, como se analisa valor a ser despedido, o resultado prático tende a ser menos expressivo.

Perguntou-se, também, se os visitantes estariam dispostos a seguir regras em favor da conservação da natureza, mesmo se isso restringisse sua própria liberdade. Dos entrevistados, $88 \%$ responderam que sim, e apenas 3\% não seguiriam as regras de conservação da natureza. No entanto, $9 \%$ não souberam dizer se seguiriam ou não tais regras.

O mesmo resultado foi encontrado por Andretta et al. (2008) onde $88 \%$ dos visitantes do complexo da Cachoeira da Fumaça em Carrancas se mostraram dispostos a seguir regras a favor da conservação da natureza.

Nesse sentido Wearing e Neil (2001, p.47) acreditam que

a única maneira de preservar e alimentar outras liberdades mais importantes (como a das comunidades que acolhem) é renunciar à liberdade de visitar ou limitar o número de visitantes. Nestes termos, a liberdade é o reconhecimento da necessidade, a necessidade de renunciar à liberdade (humana) pessoal ou individual colocando restrições ao número de visitantes e limitando o alcance das experiências de viagem dos ditos visitantes.

Os estudos de Kinker (2000) confirmam que quanto mais alta a frequência de viagens a áreas naturais para o lazer, maior o grau de conscientização ambiental do viajante.

Assim, procurou-se saber quantas viagens à natureza os entrevistados haviam realizado no último ano. Quase a metade deles (47\%) disse ter feito menos de três viagens, $21 \%$ disseram ter viajado entre quatro e sete viagens a áreas naturais e $19 \%$ 
fizeram mais de dez viagens no último ano. E ainda, 13\% dos entrevistados não haviam realizado nenhuma viagem à natureza (Figura 8 ).

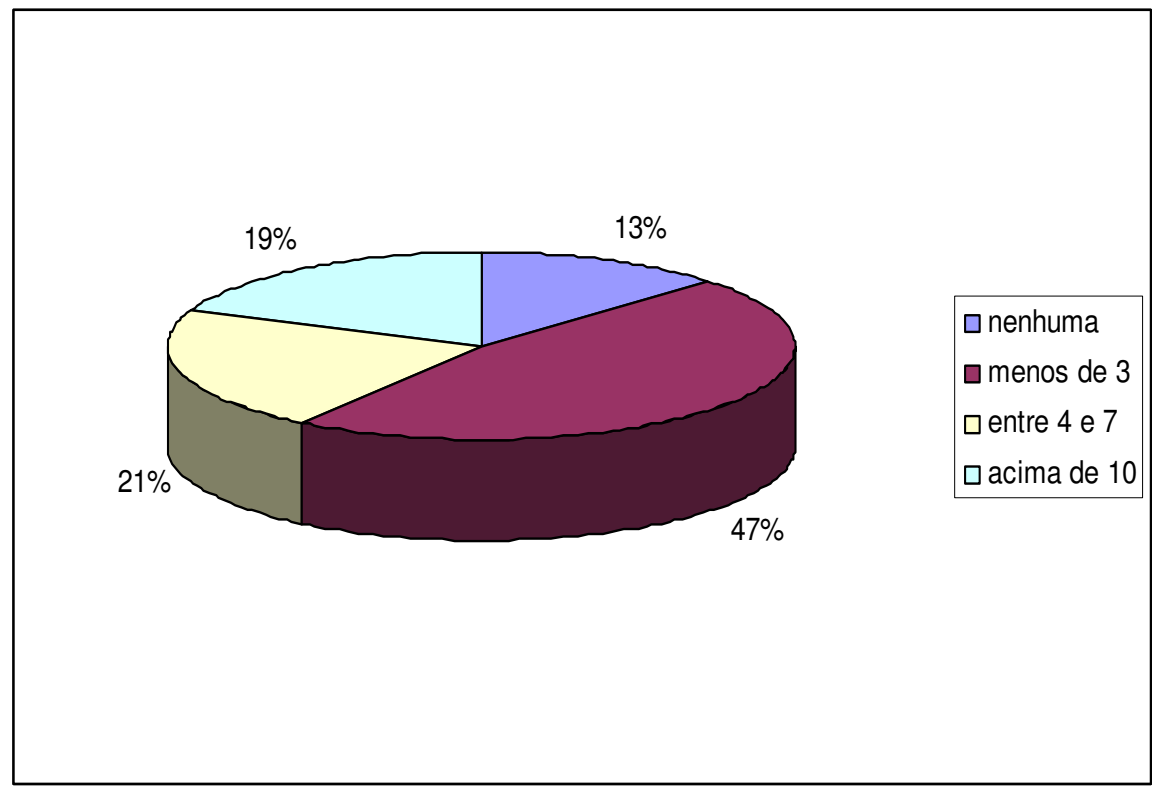

Figura 8: Número de viagens à natureza.

Para Kinker (2000) também a maneira como uma pessoa desfruta o seu passeio na natureza está relacionada com a frequência com que faz passeios. De acordo com a autora, a insegurança inicial nesse ambiente, natural do indivíduo que mora em centros urbanos, vai sendo substituída pela sensação de bem-estar a cada visita e, gradativamente, a curiosidade e o interesse pelos ambientes visitados geram 0 interesse do visitante em se informar sobre eles.

Leme e Neves (2002) acrescentam que a percepção do visitante que entra em contato com a natureza, também varia conforme a sua cultura. "Para muitos um campo aberto sem fronteiras pode ser percebido com o significado de liberdade e oportunidade, e para outros, um espaço de insegurança e desespero" (LEME; NEVES, 2002, p. 216).

Quando questionados se tinham o costume de visitar outros Parques Nacionais (Estaduais/Municipais), 67\% dos entrevistados afirmaram que sim, e apenas 33\% disseram não ter esse costume. Partindo da premissa que boa parte das pessoas quando passam a visitar uma UC com certa frequência tem a predisposição de ter atitudes mais ecologicamente corretas, o Parque pode ter nesta realidade uma boa chance de aliar esta predisposição natural com informações relevantes sobre conduta consciente em ambientes naturais (MELO et al., 2008).

Com relação à limitação de entrada dos atrativos, $71 \%$ dos entrevistados concordaram que a entrada nos atrativos deve ser limitada. Dentre as razões dadas por estes entrevistados, aparecem: 
- "Diminuir o impacto ambiental";

- "Para evitar depredação e danos à natureza";

- "Controle da produção de lixo, segurança, degradação ambiental";

- "O ambiente seria prejudicado com muitas pessoas";

- "Excesso de pessoas nunca é bom";

- "Para manter suas belezas naturais preservadas";

- "Há muitos vândalos entre os humanos";

- "Facilidade de fiscalização".

Já os $29 \%$ que não acham que deva haver limitações de entrada nos atrativos, argumentam que:

- "Todos devem ter acesso à natureza";

- "Porque todos temos um direito em comum";

- "Não vejo como o limite possa ser excedido";

- "É do povo".

Esse resultado demonstra uma conscientização ambiental por parte dos visitantes, uma vez que os mesmos se mostraram preocupados com os impactos que podem ser causados pelo excesso de pessoas num determinado local. Apesar de atualmente a maioria dos pesquisadores considerarem não existir relação direta entre o número de visitantes e a quantidade de impactos negativos em uma área, bem como a de que esses impactos estão muito mais relacionados ao tipo de ambiente visitado, ao tipo de infra-estrutura construída e ao comportamento dos visitantes do que propriamente ao número de pessoas. Mas obviamente, quanto maior o número de pessoas em determinada área, maior a chance de ocorrem impactos devido a comportamentos não adequados. O que reforça a importância de fornecimento de informações educativas e esclarecedoras que modifiquem comportamentos inadequados. Informações simples podem evitar danos irreversíveis ao ambiente e à segurança do próprio visitante.

\section{Classificação da experiência}

Segundo Van Houts (1991 apud RUSCHMANN, 2002) capacidade de carga pode ser definida como o número de pessoas que uma área pode acomodar, antes que ocorram impactos negativos no ambiente físico, nas atitudes psicológicas dos turistas, no nível de aceitação social da comunidade receptora e no nível de otimização 
econômica. Ainda de acordo com o mesmo autor, os limites mais importantes para o turismo são a capacidade de carga física, psicológica, social e econômica.

No entanto, Magro (1999) considera que os impactos sociais estão assumindo um caráter cada vez mais relevante, trata-se de um conceito novo que incorpora a qualidade da experiência do visitante à qualidade do ambiente natural, passando pelo respeito que cada indivíduo deve ter pelos demais. Entre os impactos sociais podemos citar o número de pessoas que o visitante encontra durante sua estada em uma área considerada remota.

Foi indagado aos visitantes se número de pessoas encontradas durante a visita à Serra do Cipó diferiu do esperado. A grande maioria dos visitantes $(74 \%)$ considerou a quantidade de pessoas encontradas nos atrativos dentro do esperado. No entanto, $20 \%$ dos entrevistados encontraram mais pessoas do que esperavam e apenas $6 \%$ disseram ter encontrado menos pessoas do que era esperado por eles.

Dutra et al. (2008) constatou que os dados sobre a percepção dos entrevistados em relação ao número de visitantes encontrados no Parque Estadual do Jalapão indicam que este número é geralmente menor (45\%) ou próximo ao esperado (34\%) pelos visitantes. Já no Parque Nacional do Itatiaia, de acordo com Magro (1999) a maioria dos visitantes (35\%) reportou que encontrou mais pessoas do que esperava durante sua visita, enquanto $30 \%$ disseram ter encontrado o mesmo número de pessoas do esperado.

Foi também questionado aos visitantes se a quantidade de pessoas encontradas nos atrativos influenciou de alguma forma a qualidade da visita.

Dentre os que responderam que a quantidade de visitantes estava dentro do esperado, $62 \%$ considerou que esse fato melhorou e $17 \%$ que piorou a qualidade da visita, enquanto que para $21 \%$ não alterou em nada.

Dos entrevistados que disseram que a quantidade de pessoas encontradas estava acima do esperavam, $61 \%$ também considerou que isso contribuiu para uma piora da qualidade da visita. $13 \%$ das pessoas disseram que esse fato em nada alterou a visita, enquanto $26 \%$ acharam que houve melhorou a visita.

Entretanto, dos visitantes que consideraram que a quantidade de pessoas estava abaixo do esperado, a grande maioria (86\%) acha que esse fato contribuiu para uma melhora da qualidade da visita. E os outros $14 \%$ dos entrevistados não perceberam nenhuma alteração.

Os resultados encontrados na Serra do Cipó diferem de estudos de outros autores como Kataoka (2004), Santos Junior (2006) e Dutra et al. (2008), que indicam que nem sempre a aglomeração afeta a qualidade da visitação. Kataoka (2004) justifica que muitos visitantes não percebem essa situação como um impacto, sendo até relatada como uma possibilidade maior de socialização.

Entretanto, segundo Barros e Dines (2000), algumas pessoas valorizam a sensação do isolamento e o fato de encontrarem um grupo grande no mesmo local, diminui a 
qualidade de sua experiência. Para cada indivíduo existe um ponto a partir do qual, o nível de satisfação decresce devido à presença de muitas outras pessoas. Calwson e Knestsh (1963 apud FARIA; CARNEIRO, 2001) acreditam que a capacidade de suporte comportamental está intimamente relacionada com o conceito de aglomeração, o qual, por sua vez, possui componentes tanto físicos, quanto psicológicos. O que indica a importância da inclusão de variáveis comportamentais em estudos turísticos e, portanto, a existência de uma capacidade de carga comportamental, além da capacidade de carga física. Uma vez que os impactos sociais não só afetam as relações interpessoais ou intergrupais, mas contribuem também para que o efeito educativo de uma visita à natureza seja reduzido (FARIA; CARNEIRO, 2001).

Dessa forma, pode-se constatar que o número de pessoas encontradas nos atrativos, é um fator de grande influência na qualidade da experiência dos visitantes da Serra do Cipó, o que demonstra que a percepção de aglomeração deve ser um dos indicadores utilizados para monitorar a qualidade da visita.

Para avaliar o grau de satisfação dos visitantes em relação a alguns recursos da região, Ihes foi pedido que avaliassem os serviços oferecidos em ótimo, bom, regular, ruim e péssimo (Tabela 1).

TABELA 1 - Satisfação com os recursos da região.

\begin{tabular}{|l|c|c|c|c|c|}
\hline & ÓTIMO & BOM & REGULAR & RUIM & PÉSSIMO \\
\hline Acesso à região & $35 \%$ & $52 \%$ & $9 \%$ & $3 \%$ & $1 \%$ \\
\hline Diversidade de atrativos & $38 \%$ & $53 \%$ & $9 \%$ & 0 & 0 \\
\hline Limpeza dos atrativos & $19 \%$ & $65 \%$ & $15 \%$ & $1 \%$ & 0 \\
\hline Sinalização turística & $12 \%$ & $46 \%$ & $38 \%$ & $3 \%$ & $1 \%$ \\
\hline Atendimento/Hospitalidade & $39 \%$ & $57 \%$ & $4 \%$ & 0 & 0 \\
\hline Meios de hospedagem & $39 \%$ & $54 \%$ & $6 \%$ & $1 \%$ & 0 \\
\hline Setor de alimentação & $29 \%$ & $54 \%$ & $14 \%$ & $3 \%$ & 0 \\
\hline Limpeza urbana & $19 \%$ & $57 \%$ & $20 \%$ & $4 \%$ & 0 \\
\hline Preços (geral) & $8 \%$ & $52 \%$ & $33 \%$ & $2 \%$ & $5 \%$ \\
\hline
\end{tabular}

O acesso à região teve uma grande aprovação por parte dos visitantes, visto que mais da metade deles (52\%) classificaram o acesso como bom e $35 \%$ como ótimo. Realmente a estrada que liga a capital à Serra do Cipó é muito boa, inclusive a 
parte dentro da região turística, que corta o distrito da Serra do Cipó. No entanto, o acesso a alguns atrativos, como os da Serra Morena e a maioria dos que estão dentro da área do parque, é bastante precário, pois a estrada é de terra e estreita.

Grande parte dos entrevistados (53\%) considerou boa a diversidade de atrativos da Serra do Cipó, que possui uma enorme variedade de atrativos. No entanto, o que falta é uma maior divulgação destes, pois as possibilidades são inúmeras. $65 \%$ dos entrevistados também considerou boa a limpeza dos atrativos. Em entrevista dada a Castro (2006) o Chefe do PARNA Serra do Cipó considera pouco o lixo gerado no Parque e que esse fato seja devido ao público frequentador que é, em sua opinião, muito consciente, uma vez que não há lixeiras ao longo das trilhas, e mesmo assim, não se vê lixo nas trilhas.

A sinalização é um componente importante de um destino turístico, uma vez que serve de orientação e também facilita o deslocamento dos visitantes e população local. No distrito da Serra do Cipó, $46 \%$ dos visitantes classificaram a sinalização turística como boa e $12 \%$ como ótima, mas uma parcela significativa dos entrevistados $(38 \%)$ indicou a sinalização como regular. É preciso ficar atento a esse fato, pois segundo Dutra et al. (2008) a falta de sinalização e orientação gera a imagem de um destino desorganizado e sem estruturação básica para as atividades turísticas.

$\mathrm{O}$ item melhor avaliado pelos visitantes foi o atendimento e hospitalidade da comunidade, visto que $39 \%$ deles avaliaram como ótimo e $57 \%$ como bom o atendimento e a hospitalidade local. Apenas $4 \%$ consideraram regular, sendo que as opções "ruim" e "péssimo" não foram sequer citadas.

Os entrevistados também se mostraram bastante satisfeitos em relação aos meios de hospedagem disponíveis na Serra do Cipó, uma vez que $93 \%$ deles classificaram como ótima e boa a hospedagem. A serra do Cipó conta hoje com uma enorme variedade de pousadas, campings e casas de aluguel, o aumentam as chances de agradar a todos os gostos, estilos e bolsos.

Outro item que teve classificação satisfatória foi o setor de alimentação. 29\% dos respondentes consideraram como ótimas e $54 \%$ como boas, as opções de alimentação. O que comprova os estudos de Castro (2006) onde o setor de alimentação da Serra do Cipó obteve 68\% de aprovação dos visitantes.

A limpeza urbana foi também vista de forma positiva pelos visitantes, uma vez que a maioria dos entrevistados considerou como sendo boa, a qualidade da limpeza urbana e $19 \%$ como ótima. A limpeza urbana no distrito da Serra do Cipó ocorre três vezes por semana para lixo comum e uma vez apenas para lixo reciclável. Após fazerem uma avaliação geral dos preços cobrados pelos serviços prestados no distrito da Serra do Cipó, a maioria dos entrevistados (52\%) classificou-os como sendo bons e $8 \%$ como ótimos. No entanto, $33 \%$ dos visitantes consideraram como sendo regulares, $2 \%$ acharam os preços ruins e $5 \%$ acharam péssimos os preços cobrados na região.

De uma forma geral, a maior parte dos itens avaliados obteve resultados bons 
e ótimos. Entretanto, vale ressaltar que deve ser dada atenção também às avaliações que não se mostraram satisfatórias, pois estratégias para melhoria e adequação desses itens podem garantir um aumento significativo na qualidade da experiência do visitante da Serra do Cipó.

Quando questionados se tinham o interesse de obter mais informações sobre a região da Serra do Cipó, 90\% dos entrevistados responderam que sim e apenas 10\% não gostariam de ter mais informações. O resultado demonstra que os turistas possuem interesse em conhecer mais sobre a Serra do Cipó, o que segundo Dutra et al. (2008) pode resultar na criação de atrativos culturais, como por exemplo, museus, galerias, casa da cultura, entre outros, que possibilitem a divulgação da cultura e natureza da região, além de representar um instrumento de conscientização e educação dos turistas, repercutindo assim numa conservação dos atrativos locais.

Quanto às formas de se obter tais informações sobre o local, a maioria dos entrevistados disse preferir recebê-las através de mapas/folhetos e internet (36\% pra cada) conforme Figura 9.

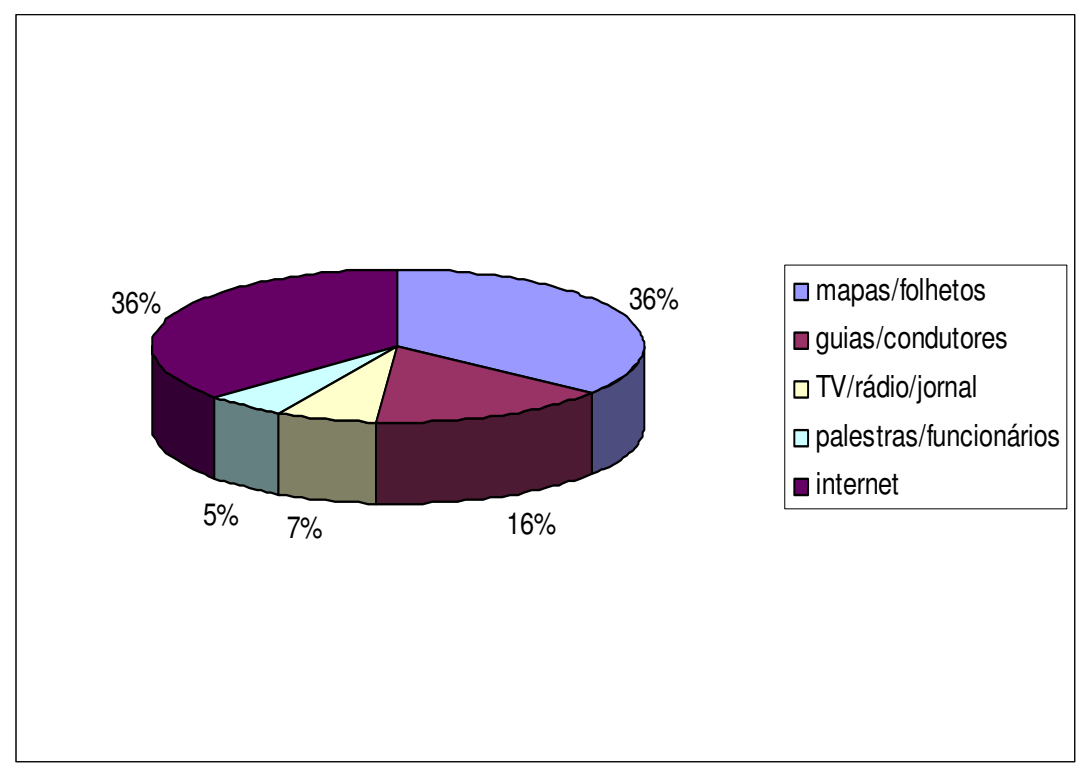

Figura 9: Formas de obter informações da região.

De uma maneira geral, a maioria (94\%) dos visitantes da Serra do Cipó se mostrou bastante satisfeita com a visita. Enquanto $5 \%$ disseram estar mais ou menos satisfeitos e apenas 1\% não se mostrou satisfeito. Petrocchi (1998) alerta que se a avaliação que o visitante faz da visita, for positiva, por certo, ele influenciará outros que poderão ir àquela cidade. Mas se a avaliação for negativa, muitos visitantes poderão escolher outros destinos, pois a oferta é muito grande no mercado do turismo. A avaliação negativa é, então, em longo prazo, uma real ameaça à sobrevivência do sis- 
tema turístico. Portanto, esforços devem ser feitos para manter o alto nível de satisfação do turista assegurando uma experiência significativa, elevando a conscientização ambiental e promovendo práticas sustentáveis entre os turistas.

Assim, 99\% dos visitantes entrevistados disseram ter a intenção de voltar à Serra do Cipó. Provavelmente, o alto índice de intenção de retorno à região pode ser devido à maior parte dos visitantes virem de cidades próximas e porque, geralmente, os visitantes que gostam e saem satisfeitos acabam indicando e recomendando o local para outras pessoas, também levam amigos e parentes para conhecerem o local, ou voltam para relembrar e ter uma nova experiência.

Para finalizar, foi deixado um espaço para que os entrevistados pudessem fazer algum comentário e/ou deixar alguma sugestão. Porém, apenas 38\% dos respondentes o fizeram. $O$ fato de a maioria dos entrevistados não ter deixado sugestões pode ser visto como um sinal de falta de percepção ambiental e/ou da falta de disposição e interesse em contribuir.

No entanto, algumas das sugestões dadas pelos visitantes, demonstram um bom nível conscientização ambiental e preocupação com a conservação do ambiente natural. Como pode ser visto nos comentários abaixo:

- "Urge educar pessoas para usar esse contato com a natureza com consciência e respeito, Educação Ambiental já!";

- "Adequar a capacidade de carga nos feriados";

- "É fundamental manter este parque limpo e preservado";

- "Melhorar a consciência das pessoas que frequentam e visitam aqui";

- "Valorizar e resgatar a cultura local e tentar não influenciar com culturas de fora, manter o local mais rústico, pois este é o diferencial. Não mudar o lugar para o turista e sim mudar o turista para o lugar";

- "A informação e a divulgação deste projeto que visa à melhoria do Parque";

Podemos destacar também, sugestões que dizem respeito à melhoria da infraestrutura local, tais como:

- "Fazer circular vans ou ônibus entre os atrativos";

- "Mapas que indicassem todos os atrativos da região e a distância percorrida até cada um, indicando o preço";

- "Mais restaurantes típicos e rústicos";

- "Melhorar a sinalização, inclusive para deixar claro que o Cipó é uma Unidade de Conservação";

- "Posto de gasolina, caixa eletrônico". 
E outras ainda, que são reivindicações pessoais, geralmente ligadas a dinheiro:

- "Acredito que as pessoas que são sitiantes do local deveriam ter privilégios no pagamento das taxas (pelo menos $50 \%$ de desconto)";

- "Cachoeiras abertas, sem cobrar";

- "Os atrativos possuem entradas muito caras, menos o Parque que tem um preço justo";

- "Preço abusivo da Cachoeira do véu da noiva".

Por outro lado, alguns comentários demonstram a falta de afinidade e mesmo o despreparo de alguns dos entrevistados em suas relações com a natureza. Isso se reflete em uma vontade dos visitantes de inserir alguns elementos da urbanidade no ambiente natural, sem considerar os impactos negativos que isso possa causar. $O$ que enfatiza o fato de alguns dos visitantes não se sentirem à vontade nesse tipo de ambiente, como demonstrado nos comentários:

- "Permissão para percorrer a trilha de carro devido às enormes distâncias para chegar às cachoeiras";

- "Banheiros químicos nas trilhas";

- "Uma dedetização seria uma boa já que tem muitos mosquitos e carrapatos";

- "Adoção de trilhas mais planas até as cachoeiras".

Sato (2007) também obteve depoimentos curiosos em seus estudos na Serra do Cipó, como: pedidos de instalação de duchas quentes e de um bondinho para levar os visitantes até a cachoeira. Sugestões que demonstram, segundo a autora, que para os visitantes, o ambiente urbano e o ambiente natural são dois mundos completamente distintos. Sendo que eles sentem-se parte apenas do primeiro e, quando estão em um ambiente natural, não se sentem inseridos nele, parte dele, e sim meros observadores da paisagem, comportando-se como tal (SATO, 2007).

Ruschmann (1997) considera o comportamento do turista de espaços naturais, contrastante. Pois, ao mesmo tempo em que ele (o turista) deseja ver uma natureza intocada, quer tocar os animais; quer "viver a natureza", porém com conforto e segurança; quer a natureza "pura", porém acessível. Para Gontijo (2003, p.183) "o problema é que não queremos abrir mão de nossos confortos, não queremos nos afastar dos mitos da sociedade moderna - do mito do possibilismo tecnológico, do mito do possibilismo monetário, do mito recente da globalização".

Hoje em dia, as pessoas são incentivadas pela mídia a ter mais horas de lazer, a "colecionarem" paisagens e espaços, assim como colecionam qualquer objeto de 
consumo. Assim, muitas vezes, realizam viagens apenas seguindo a moda, sem grandes realizações pessoais. Leme e Neves (2002) dizem que, para alguns, viajar se trata simplesmente de "carimbar o passaporte", de puro exibicionismo, fazendo desaparecer o lúdico numa divisão entre o "eu-que-realiza" e o "eu-que-observa". E que, quase sempre, o prazer do "eu-que-realiza" é sacrificado em favor do prazer futuro do "eu -que-observa", que vai apenas relatar a façanha. Assim, o foco, muitas vezes, se torna o status, o relato para o outro de que se tem condições de poder ter estado em locais diferentes (LEME; NEVES, 2002). Portanto, a relação que as pessoas terão com o local visitado é uma relação de consumo, de check list. Para Neiman et al. (2008) se não houver processos de cognição, percepção e interpretação ambiental individuais que modifiquem esta realidade, este espaço resume-se a uma bela coleção de fotos.

As sugestões deixadas pelos entrevistados, além de demonstrarem suas expectativas, indicam que há uma necessidade de ações educativas para formar e informar os visitantes. De acordo com Krippendorf (2003) uma nova compreensão das viagens e um novo comportamento durante as mesmas poderiam contribuir para desenvolver o senso de humanidade e de equidade. Em quase todas as destinações turísticas tem-se constatado a falta de "cultura turística" das pessoas que viajam, o que faz com que se comportem de forma alienada em relação ao meio que visitam. "Aprendemos a ler, a calcular, a dançar, a comprar, a dirigir, etc. Mas teríamos aprendido a viajar?' (KRIPPENDORF 2003, p.180). O autor acredita que essa grande lacuna seja responsável pelos inúmeros erros de comportamento que cometemos nas férias, assim como nossas decepções e nossa incapacidade de desfrutar plenamente da viagem.

Cole (1989 apud BARROS, 2003) acredita que alguns comportamentos inadequados possam ser modificados através de programas voltados para a educação dos visitantes. No entanto, estes programas precisam ir além de simplesmente ensinar o que os visitantes devem fazer, eles devem objetivar mudar o modo como as pessoas pensam e avaliam o seu comportamento. "Mais do que conscientizar (campo da 'razão') é preciso sensibilizar (universo restrito das 'emoções')" (NEIMAN, 2008, p. 132). Krippendorf (2003) acredita que, dessa forma, o turismo possa ser, eventualmente, enriquecedor e um estímulo para um cotidiano e uma sociedade melhores. $E$ por que não, afinal?

\section{Considerações Finais}

Destacamos neste estudo a importância de se conhecer o perfil e a percepção dos turistas que visitam Unidades de Conservação de forma a propiciar uma maior integração destes aspectos no planejamento do uso público e, consequentemente, garantir uma experiência rica e agradável aos visitantes sem causar impactos significativos aos recursos naturais e culturais da área. É válido lembrar que o perfil dos visitantes pode mudar com o tempo. Daí a importância de desenvolver um programa de monitoramento constante do perfil e opinião do visitante. 
Os atrativos naturais e culturais do local e a curta distância da região metropolitana de Belo Horizonte, acabaram por produzir um crescimento intensivo do turismo no distrito da Serra do Cipó, devido à concentração de equipamentos turísticos e por ser a principal área de apoio para o acesso (uso público) ao Parque Nacional e à APA. A Serra do Cipó possui várias destinações com diferentes graus de acessibilidade, o que sugere a continuidade de um processo de assédio turístico cada vez maior.

Dessa forma, o turismo na região da Serra do Cipó precisa de mais estudos que auxiliem no planejamento e gerenciamento do espaço turístico, do uso público e

das necessidades da comunidade local, evitando assim a deterioração do destino. É importante lembrar que as características próprias do local devem ser mantidas.

A linha que separa o Ecoturismo do turismo de massa em ambientes naturais é frágil e sutil, e pode ser ultrapassada sem que os responsáveis pelo manejo se dêem conta disso. Podemos dizer que na Serra do Cipó ocorre tanto a prática do Ecoturismo, como do turismo de massa, sem nenhuma busca por conhecimento da cultura local e de uma Educação Ambiental.

É recomendada a adoção de práticas de Educação Ambiental junto aos planos de desenvolvimento do turismo na região, a fim de minimizar os impactos causados pelo turismo tanto para a comunidade, quanto para os turistas. Assim, é de extrema importância a utilização dos princípios do Ecoturismo na região receptora da atividade turística, mesmo que ainda não haja uma definição concreta acerca do seu conceito. Dessa forma, talvez seja possível fazermos com o que o turismo venha a ser verdadeiramente econômica, social, cultural e ecologicamente sustentável, além de fonte de conservação ambiental.

\section{Referências Bibliográficas}

ANDRETTA, V.; PEREIRA, J. A. A.; MACEDO, R. L. G.; LOPES, F. W. A; VITORINO, M. R. Impactos ambientais e perfil dos visitantes no Complexo da Cachoeira da Fumaça em Carrancas / MG. Caderno Virtual de Turismo. v. 8, n.1, 2008. Disponível em $<$ http://www.ivt.coppe.ufri.br/caderno/ojs/viewissue.php?id=27> Acesso em: 26 out. 2009.

ALENCAR, E. Pesquisa em Turismo. Lavras: UFLA, 2007. 166p.

BARROS. M. I. A. de. Caracterização da visitação, dos visitantes e avaliação dos impactos ecológicos e recreativos do planalto do Parque Nacional do Itatiaia. 2003. Dissertação (Mestrado em Recursos Florestais, com opção em Conservação de Ecossistemas Florestais). Universidade de São Paulo, Piracicaba, 2003.

BARROS. M. I. A. de; DINES, M. Mínimo impacto em áreas naturais: uma mudança de atitude. In: SERRANO, C. (Org.). A educação pelas pedras: Ecoturismo e Educação Ambiental. São Paulo: Chronos, 2000. p.47-84. 
Análise do perfil, da percepção ambiental e da qualidade da experiência dos visitantes da Serra do Cipó (MG).

CASTRO. S.B. Turismo e Meio Ambiente em Município com Unidade de Conservação em seu território: estudo de caso do município de Santana do Riacho Serra do Cipó/ Minas Gerais. 2006. Dissertação (Mestrado em Turismo e Meio Ambiente). Centro Universitário UNA, Belo Horizonte, 2006.

DUTRA, V. C. ; SENNA, M. L. G. S. de; FERREIRA, M. N. e; ADORNO, L. F. M. Caracterização do perfil e da qualidade da experiência dos visitantes no Parque Estadual do Jalapão, Tocantins. Caderno Virtual de Turismo. v.8, n.1, 2008. Disponível em $<$ http://www.ivt.coppe.ufri.br/caderno/ojs/viewissue.php?id=27>. Acesso em: 16 nov. 2009.

FARIA, D. S. de ; CARNEIRO, K. S. Sustentabilidade ecológica no turismo. Brasília: UnB, 2001. 95p.

IBAMA. Instituto Brasileiro do Meio Ambiente e dos Recursos Naturais Renováveis. Plano de ação emergencial do Parque Nacional da Serra do Cipó. Brasília: Departamento de Unidade de Conservação, Divisão de Gerenciamento, 1994.

GUALTIERI-PINTO, L.; OLIVEIRA, F. F de; ALMEIDA-ANDRADE. M; PEDROSA, H. F; SANTANA, W. A. de; FIGUEIREDO, M. do A. Atividade Erosiva em Trilhas de Unidades de Conservação: Estudo de Caso no Parque Nacional da Serra do Cipó, Minas Gerais, Brasil. e-scientia, v.1, n.1, novembro, 2008. Disponível em <http:// www.unibh.br/revistas/escientia/>. Acesso em: 25 out. 2009.

KATAOKA, S. Y. Indicadores da qualidade da experiência do visitante no Parque Estadual da Ilha Anchieta. 2004. Dissertação (Mestrado em Recursos Florestais, com opção em Conservação de Ecossistemas Florestais). Universidade de São Paulo, Piracicaba, 2004.

KINKER, S. Ecoturismo e conservação da natureza em parques nacionais. Campinas, SP: Papirus, 2002. 224 p.

KRIPPENDORF, J. Sociologia do turismo: para uma nova compreensão do lazer e das viagens. 3 ed. São Paulo: Aleph, 2003. 184 p.

LADEIRA, A. S.; RIBEIRO, G. A.; DIAS, H. C. T.; SCHAEFER, C. E. G. R. Schaefer; FERNANDES FILHO, E.; OLIVEIRA FILHO, A.T. O perfil dos visitantes do Parque Estadual do Ibitipoca (PElb), Lima Duarte, MG. Revista Árvore, Viçosa-MG, v.31, n.6, p.1091-1098, 2007. Disponível em: <http://www.scielo.br/scielo.php?

script=sci arttext\&pid=S0100-67622007000600014\&lng=pt\&nrm=iso\&tlng=pt $>$. Acesso em: 16 nov. 2009.

LEME, F.B.M.L.; NEVES, S.C. Dos ecos do turismo aos ecos da paisagem: análises das tendências do ecoturimo e a perceplão de suas paisagens. Revista de Turismo y Patrimônio Cultural, v.5, n.2, p. 209-223. 2007. Disponível em <http:// www.pasosonline.org/Publicados/5207/PS060207.pdf >. Acesso em: 2 out. 2009. 
MAGRO. T. C. Impactos do uso público em uma trilha no planalto do Parque Nacional do Itatiaia. 1999. Tese (Doutorado em Ciências da Engenharia Ambiental). Universidade de São Carlos, 1999.

MATTAR, F.N. Pesquisa de Marketing: metodologia, planejamento, execução, análise. 4ed. São Paulo: Atlas, 1997. 336 p.

MELO, R. S.; ANDRADE JÚNIOR, J. A. de; LINS, R.P.; MENEZES, D. A. de. Conduta consciente e técnicas de mínimo impacto no Parque Estadual Pedra da Boca (PB). OLAM - Ciência \& Tecnologia. v.8, n.1, p. 316-334. jan/jun. 2008. Disponível em: $<$ http://cecemca.rc.unesp.br/ojs/index.php/olam/issue/view/719/showToc > Acesso em: 2 out. 2009.

NEIMAN, Z.; MENDONÇA, V.M. de; SCHLINDWEIN, M.N. Eu e a Brisa: reflexões sobre a experiência da viagem no turismo. Revista Brasileira de Ecoturismo, São Paulo, v.1, n.1, p.114-135, 2008. Disponível em: <http://www.sbecotur.org.br/rbecotur/ artigos/artigo5.pdf> Acesso em: 29 out. 2009.

NIEFER, I.A. Análise do perfil dos visitantes das ilhas de Superagui e do Mel: marketing como instrumento para um turismo sustentável. 2002. Tese (Doutorado em Engenharia Florestal) - Universidade Federal do Paraná, Curitiba, 2002.

PETROCCHI, M. Turismo: planejamento e gestão. 3를. São Paulo: Futura, 1998. $381 \mathrm{p}$.

RIBEIRO, T. G. \& CRONENBERGER, C. Perfil do visitante do Parque Nacional da Serra dos Órgãos. II Encontro Interdisciplinar de Ecoturismo em Unidades de Conservação, Itatiaia. 2007. Anais... Itatiaia, RJ, 2007. Disponível em: <http:// www.physis.org.br/ecouc/Artigos/Artigo48.pdf>. Aceso em: 18 nov. 2009.

RUSCHMANN, D. van de M. Turismo e planejamento sustentável: a proteção do meio ambiente. Campinas, SP: Papirus, 1997. 199 p.

RUSCHMANN, D. van de M. Turismo no Brasil: análise e tendências. Barueri, SP: Manole, 2002. $165 \mathrm{p}$.

SANTOS JUNIOR, O. D. dos. O desenvolvimento do turismo em Unidades de Conservação: caracterização do uso público no Parque Estadual da llha do Mel - PR. 2006. Dissertação (Mestrado em Turismo em Hotelaria) - Universidade do Vale do Itajaí, Balneário Camboriú, 2006.

SATO, C. S. Parque Nacional da Serra do Cipó, MG: percepção ambiental e estabelecimento de áreas para educação. 2007. Dissertação (Mestrado em Ciências, área de Botânica) Universidade de São Paulo, São Paulo, 2007. 
SILVA, N. P. de S. da \& COSTA NETO. A. R. da. A Educação Ambiental como instrumento de sensibilização turística em Unidades de Conservação. Revista Eletrônica Aboré - Publicação da Escola Superior de Artes e Turismo - n. 3, p. 1-8, 2007. Disponível em: <http://www.revistas.uea.edu.br/old/abore/comunicacao/ comunicacao pesq 3/Nathalin\%20Priscila\%20de\%20Souza\%20da\%20Silva.pdf >. Acesso em: 30 nov. 2009.

WEARING, S. e NEIL, J. Ecoturismo: impactos, potencialidades e possibilidades. Barueri, SP: Manole, 2001. 256p.

Renata Ferreira Campos: Centro Universitário UNA .

Email: renata001@gmail.com

Link para o currículo Lattes: http://lattes.cnpq.br/8601664579779867

Ferdinando Filetto: Universidade Federal de Lavras

Email: ffiletto@hotmail.com

Link para o currículo Lattes: http://lattes.cnpq.br/3898658861180461

Data de submissão: 01 de junho de 2010.

Data do aceite: 16 de outubro de 2010. 